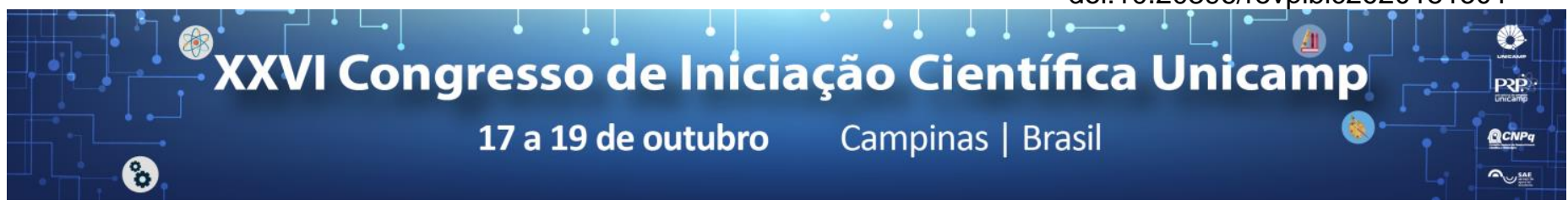

\title{
Diagnóstico e implementação de políticas públicas no âmbito do saneamento rural envolvendo famílias de baixa renda
}

\section{Thais Marim da Silva, Rafael Costa Freiria}

\begin{abstract}
Resumo
O saneamento básico ainda é muito precário no Brasil. Deste modo, é importante um bom processo de planejamento ambiental para a implementação de políticas públicas mais efetivas no setor. Este trabalho tem como objetivo estudar, de forma genérica, a problemática envolvida nos processos de gestão ambiental, especialmente o diagnóstico e implementação de políticas públicas, no âmbito do saneamento rural, abrangendo principalmente famílias de baixa renda. A pesquisa teve uma abordagem interdisciplinar, adotando o método indutivo qualitativo, realizado através do levantamento de dados e revisão bibliográfica sobre o tema. Assim, verificou-se que as políticas públicas adotadas no saneamento rural, em geral são muito escassas, e quando ocorre algum tipo de planejamento ou ação, elas não tem metodologias compatíveis com a legislação pertinente, além de ser pontuais e não abranger os quatro componentes de saneamento básico. A gestão é centralizada, falta integração entre os órgãos federativos, não envolvendo real participação e controle social, o que a torna mais excludente, local e regionalmente. Portanto, ela afeta principalmente o meio rural, em especial municípios e domicílios de baixa renda, que são geralmente excluídos com a política pública adotada. Espera-se, assim, contribuir para a compreensão da realidade do saneamento rural, sugerindo gestão de políticas públicas mais efetivas.
\end{abstract}

\section{Palavras-chave:}

Saneamento rural, políticas públicas, baixa renda.

\section{Introdução}

Cerca de $65,5 \%$ dos domicílios rurais do Brasil captam água de chafarizes, poços, cursos de água sem nenhum tratamento ou de outras fontes alternativas geralmente inadequadas para consumo humano; e $61,27 \%$, depositam seus dejetos em fossas rudimentares, lançam em cursos d'água ou diretamente no solo a céu aberto ${ }^{1}$.

Conforme dados do IBGE de 2010, quase 7,5 milhões de pessoas $(25 \%)$ estão em situação de extrema pobreza no campo, o que corresponde uma de cada quatro indivíduos que residem na área rural, ou seja, uma parcela significativa da população².

Vale ressaltar, que a Lei $n^{\circ} 11.445 / 2007$, apresenta como uma de suas diretrizes 0 atendimento da população rural dispersa, utilizando soluções compatíveis com suas características econômicas e sociais, priorizando planos e ações que visem 0 atendimento as populações de baixa renda ${ }^{3}$.

Assim, esse trabalho se propõe a investigar de forma genérica, a problemática envolvida nas políticas públicas no âmbito do saneamento rural, especialmente diagnóstico e implementação, envolvendo famílias de baixa renda.

\section{Resultados e Discussão}

$\mathrm{Na}$ área do saneamento básico, a população rural como um todo pode ser considerada como excluída. Os parcos registros de gestão encontrados na literatura geralmente não abrangem os quatro setores do saneamento.

Nas ações de políticas públicas o saneamento básico não é uma das prioridades práticas da agenda, o que dificulta os processos de universalização dos serviços. E ainda predomina no setor a visão política clássica top-down (de cima para baixo).

Esse sistema convencional adotado não permite flexibilidade e dificulta a construção junto da sociedade de projetos mais consistentes e adaptados a sua realidade, afetando principalmente a parcela da população mais pobre. De acordo com Borja (2011), os investimentos com recursos não onerosos e onerosos geralmente não abrange os municípios com maiores déficits dos serviços de saneamento, seja pela falta de capacidade desses pequenos municípios em elaborar projetos e solicitações de financiamento, seja por não se enquadrar nas regras de acesso aos recursos, persistindo uma desigualdade do acesso aos recursos onerosos, entre as macrorregiões brasileiras ${ }^{4}$.

A participação social é meramente burocrática, se reduzindo geralmente a consultas eletrônicas, audiências públicas e conselhos com membros que desconhecem sua real função. Assim, não ocorre efetiva e democrática participação social nos processos de gestão no setor.

Assim, considera-se que a problemática do saneamento básico rural não é estática, nem se resolve com um modelo e solução idêntica para todos os locais. Envolve uma série de variáveis que necessitam ser analisadas, debatidas e geridas com responsabilidade por todos (estado, população, técnicos, prestadores de serviços) para cumprir o desafio posto - a universalização.

\section{Conclusões}

A gestão de política pública adotada no setor de saneamento básico é centralizada, falta integração entre os órgãos federativos, não envolvendo real participação e controle social, o que a torna mais excludente, local e regionalmente, afetando principalmente o meio rural, em especial municípios e domicílios de baixa renda.

\footnotetext{
PNAD. Pesquisa Nacional por Amostra de Domicílios: síntese de indicadores 2014/IBGE, Coordenação de Trabalho e Rendimento. Rio de Janeiro: IBGE, 2015.

2 IBGE. Censo Demográfico 2010 - Características gerais da população, religião e pessoas com deficiência. Resultados gerais da amostra. Rio de Janeiro, 2012

3 BRASIL. Lei $n^{\circ} 11.445$ de 5 de Janeiro de 2007: Estabelece diretrizes nacionais para o saneamento básico; Diário Oficial da União, 2007.

4 BORJA, P.C. Saneamento Rural no Brasil. Cadernos temáticos para o Panorama do saneamento básico no Brasil. Brasília: Ministério das Cidades. 2011.
} 